\title{
Genetic detection to Aeromonas hydrophila proteolytic activity in milk samples (cows, buffaloes and goats) in Basra governorate
}

\author{
R. B. Zubairi \\ Department of Pharmacy, Basra Technical Institute, Southern Technical University, Basra, Iraq, Email: rawa@ stu.edu.iq
}

(Received July11, 2019; Accepted September 04, 2019; Available online 12 May 2020)

\begin{abstract}
This study aim is to determine the incidence and the virulence of Aeromonas hydrophila in raw milk, randomly collected from Basra governorate by using of polymerase chain reaction (PCR) technique. In this study, the total number of raw milk samples collected from cows, buffaloes and goats that kept from different the regions of Basra governorate were 90 samples. The PCR technique is modern method which regarded as a reliable tool to detect virulent gene of the A. hydrophila isolates. The PCR assays using the primers sets SerAh-F and SerAh-R resulted in the amplification of 650-bp bands from the targeted proteases gene of the A. hydrophil. The result of the present study showed that the results of PCR concerning the proteolytic activity of A. hydrophila in the tested raw milk samples according to animals' source. The higher percentage of the proteolytic activity was found in the cow's raw milk samples $40 \%$ and in the buffalo's milk samples was $26.7 \%$ while, the proteolytic activity did not find in the goat's milk samples. The association between the source of the milk sample and proteolytic A. hydrophila positive results was considered to be statistically highly significant. The higher percentage of the A. hydrophila isolates found in the raw cow milk was $40 \%$, and the A. hydrophila isolates found in the raw buffalo milk was $26.7 \%$, while, the A. hydrophila isolates did not find in the goat milk.
\end{abstract}

Keywords: Virulent factors, Psychrotrophs, Proteases, SerAh-F, SerAh-R Available online at http://www.vetmedmosul.com, (c) 2020, College of Veterinary Medicine, University of Mosul. This is an open access article under the CC BY 4.0 license (http://creativecommons.org/licenses/by/4.0/).

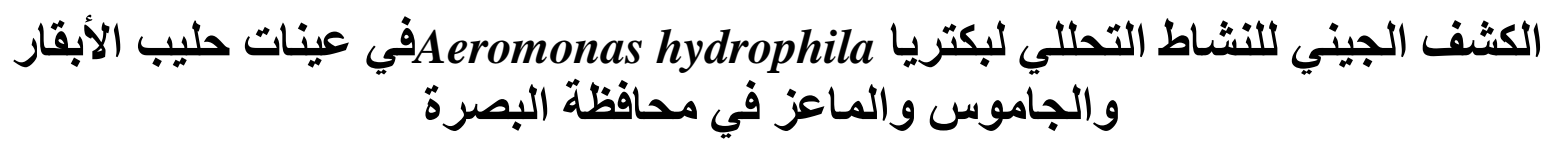

$$
\text { رواء بناي زبيري }
$$

$$
\text { قسم الصبيلة، المعهد التقني البصرة، الجامعة التقنية الجنوبية، البصرة، العراق }
$$

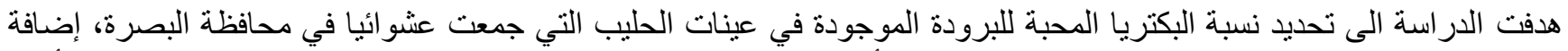

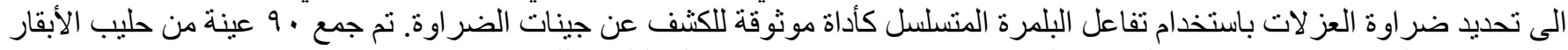

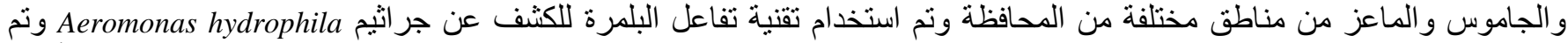

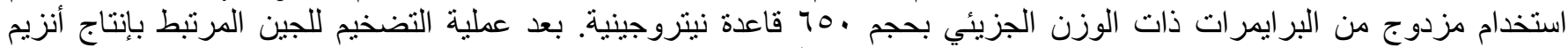

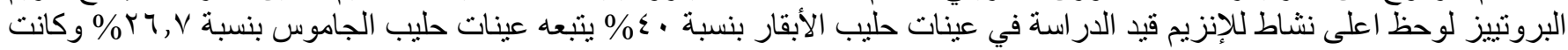

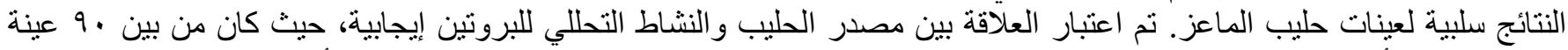

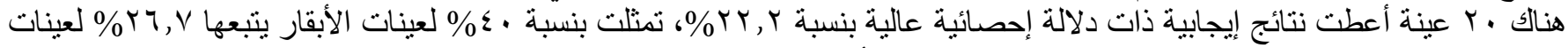

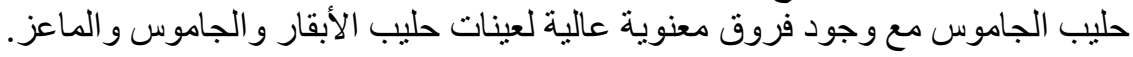




\section{Introduction}

Aeromonas species are facultative anaerobic gramnegative microscopic organisms. It related to the family Aeromonadaceae, which is frequently isolated from various food and environmental sources including sea, river, fresh and ground water (1). The amassing information showing that $A$. hydrophila is the causal operator for $85 \%$ of human gastrointestinal issue (2). A. hydrophila is regarded the major pathogen causing extreme diarrhea and extraintestinal contaminations in people (3). There are unassuming data on the commonness of Aeromonas species of mammals other than a man. Aeromonas has the ability to produce the various virulent factors which included the different types of hemolysins such asaerolysin, proteases, adhesions (adherence intervened by pili), invasins, a heat labile enterotoxin, phospholipase, and lipase $(4,5)$. Lots of proteases delivered by psychrotrophic microscopic organisms are steady even under ultra-high temperature (UHT) condition and proceed actively in dairy products (6). A. hydrophila has a various extracellular catalyst, including proteases, hemolysins, and enterotoxins. A portion of the toxin has been biochemically portrayed, however, their particular role in the pathogenicity of A. hydrophila have not decided up to this point. The two noteworthy extracellular proteolytic activities of A. hydrophila that have been depicted similar to this, a 38-kDa thermostable metalloprotease and a $68-\mathrm{kDa}$ temperature-labile serine protease are found in basically A. hydrophila culture supernatant (7). Isolation of Aeromonas spp. announced from raw milk, yogurt, and cheeses (7-9). The estimation of microbial tainting of cow's raw milk is fractional by cow's healthiness, cleanliness surroundings where dairy cows are housed, drained, strategies for udder readiness, draining system, techniques for cleaning, sanitation of draining machines and milk cisterns (10). The capacity of milk under refrigerated for the significant lot before preparing is segregating for development of psychrotrophs which may transform into the transcendent microflora (11). Beside, its developing worry as a blood borne pathogen A. hydrophila could take an interest in disintegration of the food store at refrigeration temperature due to its capacity to grow up and make thermo-resistant extracellular proteins (lipase, protease, amylase, and nuclease) that is ready to defiling significant milk constituent and consequently change the nature of completed dairy products (12). Any way little is perceived concerning the role of milk in the spread of these pathogens so this investigation was embrace as a component of an endeavor to decide the role of milk in the study of disease transmission of Aeromonas contamination, the propriety of the specific media for the restoration of the living being, the proteolytic action of detached $A$. hydophilia.
The targets of this investigation were to decide the occurrence of $A$. hydrophila in raw milk which randomly gathered from Basra governorate. As well as to determine the virulence of the isolates by using of PCR strategy as a reliable tool to detect virulent gene of some A. hydrophila isolates (Protease).

\section{Materials and methods}

Ninety raw milk samples were collected randomly from cows, buffaloes, and goats from different farms in Basra governorate. Aseptically placed into sterilized test tubes and transport to the research laboratory for investigation by using cooler box. The milk sample stored in refrigeration conditions for 3 days. The activation step recognized in the present study was prepared the $4.5 \mathrm{~mL}$ of Luria-Bertani broth inoculated with the raw milk samples at a concentration of $1 \%$ and incubation for $18 \mathrm{~h}$ at $37^{\circ} \mathrm{C}$. Culture stocks were ready in LB broth comprising sterilized glycerol at a concentration of $20 \%$ and were cold at $-20^{\circ} \mathrm{C}$. Before each investigation, the isolates were cultivated two successive periods in LB broth (13).

\section{PCR Amplification}

To confirm the presence of proteolytic GNP DNA, a standard diagnostic PCR was carried using one pair of primers designed by Machado et al. (13) including SerAh A. Hydrophila (650bp) were oligonucleotide sequence for SerAh-F primer was 5-TTCCTCCTACTCCAGCGTCG-3, and for SerAh-R 5-TGATGATCCAGGCTCACGGT-3.

\section{Proteolytic Enzymes}

The manufacture of extracellular proteolytic enzymes was resolute by agar-diffusion assays on plate count agar containing nutrient agar complemented with $10 \%$ skim milk powder. The plates were incubated at $25^{\circ} \mathrm{C}$, for $18-24 \mathrm{~h}$. The occurrence of clear zones around the colonies was an indication to the proteolysis.

\section{Statistical analysis}

Statistical analysis was done by using SPSS software from 11 to demonstrate any association between the results, the exact Fisher test and Pearson's chi-squared test with Yates correction were used to the limit of significance at level $\mathrm{P}<0.05$.

\section{Results}

\section{PCR detection of proteolytic activity}

The results of the present study showed that the higher proteolytic activity was observed in the cow raw milk samples $12(40 \%)$, followed the buffaloes milk samples 8 samples (26.7\%). While, the presence of proteolytic A. hydrophila in goats milk samples was not found. The 
association between source of milk sample and proteolytic A. hydrophila positive results was considered to be statistically highly significant $(\mathrm{P}<0.01)$. Out of 90 raw milk sample $20(22.2 \%)$ samples were positive for proteolytic A. hydrophila. The positive cow milk samples represent $40 \%(12 / 30)$ of the total tested cow milk samples followed by $26.7 \%(8 / 30)$ of the buffalo milk samples with high significant difference $(\mathrm{P}<0.01)$ among cows, buffaloes and goats milk sample (Table 1 and 2).

Table1: PCR detection of proteolytic activity of $A$. hydrophila in raw milk

\begin{tabular}{lcc}
\hline Animals & $\begin{array}{c}\text { Positive PCR } \\
\text { No. }(\%)\end{array}$ & $\begin{array}{c}\text { Negative PCR } \\
\text { No. }(\%)\end{array}$ \\
\hline Cow & $12(40)$ & $18(60)$ \\
Buffalo & $8(26.7)$ & $22(73.3)$ \\
Goat & 0 & $30(100)$ \\
\hline Total & 20 & 70 \\
\hline
\end{tabular}

Table2: Distribution of the positive PCR in total number tested milk samples

\begin{tabular}{lcccc}
\hline \multirow{2}{*}{ PCR } & \multicolumn{4}{c}{ The milk samples no. (\%) } \\
\cline { 2 - 5 } Positive & Cow & Buffalo & Goat & Total \\
Negative & $18(60.0)$ & $8(26.7)$ & $0(0)$ & $20(22.2)$ \\
Total & 30 & $22(73.3)$ & $30(100)$ & $70(77.8)$ \\
\hline
\end{tabular}

\section{Discussion}

The responsibility of raw milk as a method of transportation of causing milk borne diseases is very much perceived (14).The microorganisms are regarded as a causative agent which causing mastitis. The milk borne pathogens can get to enormous numbers in mammary tissue and later release into milk. These microorganisms are normally present on homesteads (feed, water, faces, and soil) and would thus be able to taunt the udder and nipples of the bovine and get into milk (9).

Aeromonas and Macrococcus have been disengaged from the raw dairy animals' milk (14-17). A. hydrophilia was the most overall species separated from the various types of tests $13.4 \%$ (39/292) (18). Subashkumar et al. (3) announced an aggregate of 105 milk sample was analyzed for A. hydrophila and $17.14 \%$ of the milk sample observed to be contaminated with A. hydrophila. The frequency and property of Aeromonas species in milk is the vehicle for the spread of Aeromonas gastroenteritis, due to the consequent treatment of the milk. A portion of the strains are difficult to separate from diarrhea-associated strains and ready to deliver exotoxin at $37^{\circ} \mathrm{C}$ and cling to the epithelial cells. The information announced in Ahmed et al. (19) demonstrated that the distributions of virulence factor, to manage the pathogenicity of Aeromonads, is diverse in clinical and environmental test. The protease generation was begun all the more over and again in the samples, Ahmed likewise demonstrated that protease creation with higher bond limit, among strain separated from clinical sample (19). These are in concurrence with those revealed by Sechi et al. (20).

Variables of the virulence factors represent by extracellular proteases, hemolysins, and cytotoxins are produced by single virulent and a virulent strain of $A$. hydrophila to a similar inclusion (20). This reality just as the nonappearances of the relationship between the comparing action and degree of virulence may perhaps demonstrate to subjective factors as opposed to quantitative ones that include in the pathologic procedures (19). The lysis of psychotropic microbes may prompt the arrival of warmth safe proteolytic enzyme. The microflora of raw milk has been accounted for to change contingent upon the area of the herd, rearing practices, and lactation period (18). The present examination used PCR the most encouraging strategies for the quick and explicit analysis of numerous microscopic organisms in the various milk samples.

Bedeltavana et al. (21) showed that the PCR-ribo typing and phenotypic portrayal could steady in tracking contamination routes for the creation line of milk purification. Also, the target gene, the augmented piece measure and the contaminant microbiota can be influenced to affectability of PCR when using the raw milk sample (21). Along these lines, the promote of DNA extraction and utilize of target gene are the principle basal article in the present study. Machado et al. (13) showed that this technique as a one of three strategies used to promote DNA extraction and decrease the incidence of PCR inhibitor in the DNA arrangement and the investigation of Maurer (22) and Pirondini et al. (23) who referenced that definite planning of DNA sample is serious to ensure a mitigation or expulsion of PCR inhibitors and the achievement of the PCR procedure $(13,24)$. These two studies bolsters what was done in the present investigation.

The contaminant microorganisms in raw milk, the allencompassing statistic supper than $108 \mathrm{cfu} / \mathrm{mL}$ following four days of hatching at $70^{\circ} \mathrm{C}$ can likewise add to diminish in the PCR sensitivity for recognition of considered psychrotrophs Marchand et al. (24) saw a decrease in the PCR sensitivity in nearness of different poisons, additionally other microbial species are probably going to be a rule microscopic organisms in the cooled raw milk (24). The primers SerAh-F/SerAh-R650bp utilized by Machado et al. (13) recognize the protease-encoding gene just in the A. hydrophila. The examination of the enhanced result of protease-encoding genes may show increment in the psychrotrophs populace and over-burden protease movement in raw milk for the outcome to three days of 
refrigeration to raw milk with consequent improvement of considered psychrotrophs.

In connection to the utilization of target gene and the size of the developed part, which referenced A. hydrophila is the primary masses of the microorganisms in cooled raw milk. The quick acknowledgment for these microscopic organisms can be passed out by the method for expanding protease-encoding qualities from this species (13). Consequences of other examination demonstrated to all isolates of the capacity were protease makers in varying degree. The distinction in the capacity of the segregates to create protease were attributable to a hereditary variety of beginnings mindful underway of protease. Inside other investigation, it found that $100 \%$ of A. hydrophila detach can create protease with various degrees. Which in concurrence with our study (25). In the present investigation A. hydrophila identified in $40 \%$ of bovine raw milk. In distinction Melas et al. (26) had announced that 25 $(15.9 \%)$ of (138) the dairy animals' milk sample were polite with A. hydrophila.

In eleven dairy animals' milk test $7.9 \%$ is tainted with different Aeromonas spp. Eight (14.0\%) of the 57 milk tests inspected, were sullied of A. hydrophila (26). In studies which concurrence with current outcomes, found that psychotrophic populace cooled at $5-10^{\circ} \mathrm{C}$ enhanced, especially more than at $0-5{ }^{\circ} \mathrm{C}$. This outcomes in concurrence with the investigation by Rasolofo et al. (27) that discovered psychotrophic populaces expanded inside $72 \mathrm{~h}$ when refrigerated at $8^{\circ} \mathrm{C}$ not at $4^{\circ} \mathrm{C}$, and that the elements of microscopic organisms indicated huge variety for samples from cow, buffalo, and goat $(27,25)$.

Other study uncovered that the capacity of $A$. hydrophila to deliver virulence factors and attack epithelial cells while put away at refrigeration temperature for 7-10 days $(28,29)$. Likewise, a proof $(100 \%)$ of Aeromonas spp. cytotoxic impact was constant at refrigeration temperature $(2,30)$. Our examination found a superior pervasiveness of protease in cow sample, among strains isolated from samples. These discoveries are in concurrence with those revealed by $(19,20)$. Studies in addition confirmed of proteolytic activity is affected by culture medium and temperature (6). The heat resistant protease secretability of Aeromonas spp detailed by different scientists $(13,18,31)$. Cooling of raw milk for delayed period, can improve the loss of excellence from the likelihood of proteolytic psychotrophic microorganism. The hidden danger of these psychotrophic microorganisms for human health fortifies the need to show these microorganisms in milk and dairy product. Occurrence of Gram negative psychrotrophs and their protease, lipase, and biofilm catalyst in milk implying that milk is a vehicle to transmission of these microorganisms, due to the subsequent administration of the milk. Some of strains were difficult to separate from the diarrhea- related strains that ready to create exotoxin at $37^{\circ} \mathrm{C}$ and hold fast to epithelial cells.

Gomashe et al. (32) detailed that Aeromonas species had proteolytic activities at room temperature yet extreme lessening in action was distinguished at high temperatures (32). Distinguished frailty of raw milk due to proteolysis action at psychotrophic concentration surpassing $106 \mathrm{cfu} / \mathrm{ml}$. In the interim proteolytic catalyst's generation by psychotrophic microscopic organisms emerges close-by the completion of the logarithmic stage and advances through the stationary stage milk at a proportion of 16 and $7 \%$ individually.

The current results revealed that the gram negative psychrotrophs (GNP) contaminated overall $24.7 \%$ observed in 90 raw milk sample collection from studied animals of different species in 30 cows, 30 buffaloes, and 30 goats. Higher ratio of the GNP contamination was observed in cows $12(40 \%)$ followed by followed by buffalo's milk samples in which 8 samples $(26.7 \%)$ were positive and negative results for the presence of proteolytic $A$. hydrophila in goats milk samples.

The influence of the animal's genus on the multiplication result of the examined gene product of the GNP in cow, buffalo, and goat raw milk which was estimated to be highly statistically significant $(\mathrm{P} \leq 0.001)$. This outcome shows that there was a distinction in the PCR positivity ratio among the three types of creature's raw milk. That distinction in the GNP PCR inspiration proportion and affectability of the methodology must perceive to the participation of lipid in milk.

This study demonstrated that raw goat milk ought not be put away for over multi day at $4^{\circ} \mathrm{C}(33)$. When put away for in excess of $54 \mathrm{~h}$ in a dairy plant tank at refrigerated temperature the microbial populace moved, with Pseudomonas and Acinetobacter ending up progressively predominant. This concurred with the discoveries of this investigation about goat milk. The populace shifts which happen during long term stockpiling at refrigeration temperature at $\leq 4^{\circ} \mathrm{C}$. Learns about goat milk demonstrated that microscopic organisms inside the Lactococcus and Streptococcus genera commanded the raw milk microflora when accumulated up to $24 \mathrm{~h}$, yet expanded capacity brought about an outgrowth of Pseudomonas and Acinetobacter, which contained over $60 \%$ of the all-out populace at 72 hours (18). The increase of different bacterial species which not in participation to any noteworthy level in the samples and furthermore a lesson of the novel predominant species equivalent to note by $(34,35)$.

Despite this present variety in the GNP PCR positivity proportion among the three gathering of creature's raw milk. The outcome affirmed the milk item was in decreased cleanliness condition this fact exhibited by before studies; Munsch et al. (36) who referenced the 
psychotrophicmicroorganisms are not a piece of natural bacterial populace on the udder, along these lines the occurrencein raw milk is totally the result subsequent to infectivity of after milking (37). Also virulence of gene at different in the activation related with environment (38).

The use of PCR technique require four hours after the primary isolation. Also provide analytical information, may take some days in the usual test for detection bacteria. End result show a high degree of specialty and more accurate in detection of bacteria as well as it provided the effort, speed and cost in diagnosing the pathogenic bacteria (39).

\section{Conclusion}

Psychotrophic microbes are regularly present on homesteads and in this way can taint the outside of nipples and udder of the bovines and gets into milk. A. hydrophilia it is the for the most part overwhelming species disengaged from exceptional types of test. Some of strains were indistinguishable from looseness of the bowels related strain and ready to create exotoxin sp. The improvement of DNA extraction and utilizations for target quality significant essential things in this investigation and we utilized. The preliminaries SerAh-F/SerAh-R, 650bp to recognize the protease-encoding quality just in the $A$. hydrophila. The examination of the intensified result of protease-encoding quality can be an indication of improve in the psychrotrophs populaces and over-burden protease movement in crude milk as result to three days stockpiling of raw milk in refrigeration by later upgrade of considered psychrotrophs. Result demonstrated that A. hydrophila identified in $40 \%$ of cow crude milk and this distinction in capacity of the disengages for produce protease are because of hereditary variety of beginnings mindful into the generation of protease. Likewise found that psychotrophic populaces refrigerated at $5-10^{\circ} \mathrm{C}$ enhanced more than those at $0-5^{\circ} \mathrm{C}$. The populace shifts which happen during long haul stockpiling at refrigeration temperature $\leq 4^{\circ} \mathrm{C}$.

\section{Acknowledgment}

I am grateful to all of those with whom I have had the pleasure to work during this and other related articles. I would especially like to thank Dr. Fawzia Ali. As my teacher and mentor, he has taught me more than I could ever give him credit for here. He has shown me, by his example, what a good scientist (and person) should be. Also I would like to thank reviewers for assistance comments that greatly improved the manuscript.

\section{References}

1. Fernández-BravoA,JoséFiguerasM.AnUpdateontheGenus Aeromonas: Taxonomy,Epidemiology,andPathogenicity.microorganismsJ.2020;8( 129):2-39.https://doi:10.3390 microorganisms8010129.

2. AsmaaT, Heba A,Rasha MM, Attia A, Ibrahim E, Abeer EA. Molecular characterisation, genotyping and survival of Aeromonas hydrophila isolated from milk, dairy products and humans in Egypt. Inter Dairy J.2016;63:52-58.https://doi: 10.1016/j.idairyj.2016.07.011

3. Subashkumar R, Thayumanavan T, Lakshmanaperumalsamy P.RAPD and ERIC-PCR typing of virulent Aeromonas hydrophila isolated from children with acute diarrhoea. J Cell MolBio. 2014;1(1):12. http://jcmb.halic.edu.tr

4. Liang X,Zhaoxu M,Lanwei Z,Yanhua C, Xue H,Huaxi Y.The diversity and proteolytic properties of psychrotrophic bacteria in raw cows' milk from north China. Int Dairy J. 2016;66:34-41. http://dx.doi.org/10.1016/j.idairyj.2016.10.014

5. Alperi A, Figueras MJ. Human isolates of Aeromonas possess Shiga toxin genes (stx1 and stx2) highly similar to the most virulent gene variants of Escherichia coli. Clin Microbiol Infect. 2010;16(10):15637.https:// doi: 10.1111/j.1469-0691.2010.03203.x

6. Zhang S, Li H,UlukoH, LiuL,PangX,LvJ. Investigation of protease production by Pseudomonas fluorescens BJ-10 and degradation on milk proteins. J Food Proc Pres. 2015;39:2466-2472. https://doi.org/10.1111/jfpp.12496

7. Alberto C,Javier Y, Alejandro T,Maria SA,Carmen $H$, Jose A,German N.A Major secreted elastase is essential for pathogenicity ofAeromonas hydrophila.Infect Immuol.2000;68(6):3233-3241. https:// doi: 10.1128/IAI.68.6.3233-3241.2000

8. FreitasAC, NunesMP, MilhomenAM,RicciardiID. Occurrence and characterization of Aeromonas spp. in pasteurized milk and white cheese in Riode Janeiro Brazil. J Food Pro.1993;56(1):62-65.https:// doi/pdf/10.4315/0362-028X-56.1.62

9. NagwaA, Salah A, Madeha A, Magdy S. Enumeration and characterization of Aeromonas spp isolated from milk and some dairy products in Sharkia governorate Egypt.Alexandria $\mathrm{J}$ Vet Sci.2014;40:52-64. https://doi.org/10.5455/ajvs.49073

10. Bramley A,Mckinnon C. The microbiology of raw milk. New York: Elsevier; 1990. 163-208 p. https://doi.org/10.1002/0471723959.ch2

11. Sorhaug T, Psychrotrophic V. Total bacterial count in bulk milk samples. Vet Med Czech.1992; 47(8): 227-233 . https:// doi.org/ 10. $17221 / 5829$-vetmed

12. Sørhaug T, Stepaniak L. Psychrotrophs and their enzymes in milk and dairy products: Quality aspects Trends in Food Science \& Technology J. 1997;8(2):35-41. https://doi.org/10.1016/S0924-2244(97)01006-6

13. Machado SG,Bazzolli DMS, Vanetti MCD. Development of a PCR method for detecting proteolytic psychrotrophic bacteria in raw milk. Int Dairy J.2013;29:8-14. https://doi.org/10.1016/j.idairyj.2012.09.007

14. Taylor R,Weinstein M, BrynerH. Campylobacter fetus infection in human subjects association with raw milk. Am J Med.1979;66:779783. https://doi.org/10.1016/0002-9343(79)91116-1

15. ArcuriF, SilvaL, Brito P, BritoF, LangeC, MagalhaesA. Counting, isolation and characterization of psychrotrophic bacteria from refrigerated raw milk. Ciencia Rural.2008;38:2250-2255. https://doi.org/10.1590/s0103-84782008000800025

16. Delgado S, RachidC, FernandezE, RychlikT, AlegriaA, PeixotoS. Diversity of thermophilic bacteria in raw, pasteurized and selectivelycultured milk, as assessed by culturing, PCRDGGE and pyrosequencing. Food Microbiol.2013; 36:103 -111. https://doi.org/ 10.1016/j.fm.2013.04.015

17. RasolofoA, LaPointeG, Roy D. Assessment of the bacterial diversity of treated and untreated milk during cold storage by T-RFLP and PCRDGGE methods. Dairy Sci Technol.2011;91:573-597.https:// doi: 10.1007/s13594-011-0027-4

18. Ling L, John J, Ling F, Qingkun Z, Yan T, Li Huang, Daxi R, Pan Y.Characterization of the indigenous microflora in raw and pasteurizedbuffalo milk during storage at refrigeration temperature by high-throughput sequencing.JDairy Sci.2016; 99(9):7016-7024. https://doi.org/10.3168/jds.2016-11041 
19. Ahmed M,Hoda Z,Nibal H, Nihad M.Phenotyping, virulence characteristics ofAeromonas species and the effect ofessential plant oils as antimicrobial agents againstpathogeneticsisolate from different source.Am J Infect Dis.2014;10 (1):21-35.https:// doi:10.3844/ajidsp.2014.21.35

20. Sechi A, Deriu A, Falchi P, Fadda G, Zanetti S. Distribution of virulence genes in Aeromonas spp. isolated from Sardinian waters and from patients with diarrhoea. J Appl Microbiol.2002;92:221-227. https://doi.org/10.1046/j.1365-2672.2002.01522.x

21. BedeltavanaA, HaghkhahM,NazerA. Phenotypic characterization and PCR-ribotyping of Pseudomonas fluorescens isolates, in tracking contamination routes in the production line of pasteurized milk. Iranian J Vet Res Shiraz Uni.2010;11(3):1421-1429 https://doi.org/10.3168/jds.s0022-0302(01)70174-9

22. Maurer J. PCR methods in foods. $1^{\text {st }}$ ed. New York: Springer; 2006:69-90.https://doi.org/10.1007/0-387-31702-1

23. PirondiniA, BonasU, Maestri E, VisioliG, MarmiroliM, Marmiroli N.Yield and amplificability of different DNA extraction procedures for traceability in the dairy food chain. Food Control.2010;21:663668. https://doi.org/10.1016/j.foodcont.2009.10.004

24. Marchand S, Vandriesche G, Coorevits A, Coudijzer K, De Jonghe V, Dewettinck K, De Vos P, Devreese B, Heyndrickx M, De Block J. Heterogeneity of heatresistant proteases from milk Pseudomonas species. Int J Food Microbiol. 2009;133:68-77. https://doi.org/10.1016/j.ijfoodmicro.2009.04.027

25. Maeis T, Hameed M, Asmaa A. Isolation and Identification of protease producingAeromonas hydrophila. J Al-Nahrain Uni Sci.2014;17(1):143-147. https://doi.org/10.22401/jnus.17.1.19

26. Melas DS, Papageorgiou DK,Mantis AI. Enumeration and confirmation of Aeromonas hydrophila, Aeromonas caviae, and Aeromonas sobria isolated from raw milk and other milk products in Northern Greece.J Food Prot.1999;62(5):463-6. https:// doi.org/ 10.4315/ 0362-028x-62.5.463

27. Rasolofo EA,St-Gelais D, LaPointe G,Roy D. Molecular analysis of bacterial population structure and dynamics during cold storage of untreated and treated milk. Int J Food Microbiol. 2010;31(138):1-2. https://doi.org/10.1016/j.ijfoodmicro.2010.01.008

28. MajeedK, EganA, Mac I. Production of exotoxins by Aeromonas spp at 5 C.J Appl Bacteriol.1990;69:332-337. https:// doi.org/10.1111/j. 1365-2672. 1990.tb01524.x

29. Mateos D, Anguita J, Naharro G, Paniagua C. Influence of growth temperature on the production of extracellular virulence factors and pathogenicity of environmental andhuman strains of Aeromonas hydrophila. J Appl Bacteriol.1993;74:111-118. https://doi.org/ 10.1111/j .1365-2672.1993.tb03003.x

30. Grassi M, Civera T,Turi R. Isolation of cytotoxic Aeromonas spp. from food. Vet Res Commu.2003;27:305-306. https://doi.org/ 10.1023/b:verc.0000014166.31914.1a

31. Hantsis E, Halpern M. Chryseobacterium hai- fense sp. nov., a psychrotolerant bacterium isolated from raw milk. Int J Syst Evol Microbiol.2007;57:2344-2348. https//dOI: 10.1099/ijs.0.65115-0

32. Gomashe AV, Dharmik PG, Zade BN. Proteolytic activity among psychrotrophic bacteria isolated from refrigerated raw milk. Inter $\mathbf{J}$ Innovations Bio Sci. 2012;2(3):100-103. https://doi.org/ 10.1111/j .1471-0307.2009.00542.x

33. Fonseca CR, Bordin AM, Fernandes CE, Rodrigues CH, Corassin AG, Cruz CA, Oliveira F. Storage of refrigerated raw goat milk affecting the quality of whole milk powder. J Dairy Sci.2013;96:4716-4724. https://doi.org/10.3168/jds.2012-6120

34. Lafarge V, Ogier JL, Girard MV, Leveau JY, Gruss A, DelacroixBA. Raw cow milk bacterial population shifts attributable to refrigeration. ApplEnviron Microbiol.2004;70:5644-5650. https://doi.org/10.1128/ aem. 70.9.5644-5650.2004

35. Raats D, Offek M, Minz D, Halpern M. Molecular analysis of bacterialcommunities in raw cow milk and the impact of refrigeration on its structureand dynamics. Mol BiolEvol.2011;28:2731-2739. https://doi.org/10.1016/j.fm.2010.10.009

36. MunschP,AlatossavaT. Phenotypic characterization of raw milk associated psychrotrophic bacteria. MicrRes.2005;161:334-346. https://doi.org/10.1016/j.micres.2005.12.004

37. Barbano DM, Ma Y,Santos MV. Influence of raw milk quality on fluid milk shel life. JDairy Sci.2006;89(E):15-19. https://doi.org/10.3168/jds.s0022-0302(06)72360-8

38. Sadeq J.N,Fahed Kh.K,Hassan H.J.detection of Escherichia Coli hylAgene and Staphylococccus aureus Sea gene in raw milk buffaleosusing RT-PCR technique in AL-Qasisiyah province.Iraqi J.of Veterinary Sciences. 2018;32(1):87-92. https://doi: 10.33899/ijvs. 2018. 153815

39. Saleh Z.F, Al-Muhana B.M, Hamdan Kh, Jawad M.S, Klaif S.F. Isolation and identification of Salmonella typhimurium bacteria with detection of type-1 fimbriae coding gene by polymerase chain reaction (PCR) technique. Iraqi Journal of Veterinary Sciences.2019; 33(1): 195-199.https://doi:10.33899/ijvs.2019.162961 